\title{
Meningkatkan Keaktifan Dan Hasil Belajar Mahasiswa Melalui Metode Diskusi Kelompok Berbasis Pembelajaran Kooperatif Model Learning Together Pada Matakuliah Konsentrasi Pemasaran Di Fakultas Ekonomi Universitas Muhammadiyah Sumatera Utara
}

\author{
Dewi Andriany ${ }^{1)^{*}}$, Nel Arianty ${ }^{2)}$ \\ Universitas Muhammadiyah Sumatera Utara \\ *Email:dewiumsu@yahoo.com
}

\begin{abstract}
ABSTRAK
Penelitian ini bertujuan untuk mengetahui sejauh mana mahasiswa dapat terlibat secara aktif di dalam kelas dengan menggunakan metode diskusi kelompok berbasis pembelajaran kooperatif model learning together, dan juga untuk mengetahui sejauh mana mahasiswa dapat mengemukakan pendapat dan memberikan tanggapan terhadap pendapat teman kelasnya secara komunikatif dengan menggunakan metode diskusi kelompok berbasis pembelajaran kooperatif model learning together. Pendekatan yang digunakan adalah melalui penelitian tindakan kelas (classroom Action Research), melalui metode pembelajaran kooperatif. Langkah yang ditempuh dengan tahapan: (1) plan, (2) action, (3) observation, (4) reflection. Hasil penelitian menunjukkan bahwa: (1) Selama proses pembelajaran mengunakan metode diskusi kelompok berbasis pembelajaran kooperatif metode learning together keaktifan belajar mahasiswa dapat meningkat karena mahasiswa diberdayakan dan diberi kepercayaan dan terlibat secara aktif dalam kegiatan belajar. Ketercapaian persentase rata-rata keaktifan belajar siswa terus meningkat dimana pada tahap pra siklus hanya sebesar 34,1 $\%$, kemudian mencapai persentase $65,8 \%$ pada siklus 1 dan meningkat lagi menjadi $92 \%$ pada siklus 2 .(2)Dampak positif dari meningkatnya keaktifan belajar adalah pada hasil belajar mahasiswa yang juga mengalami peningkatan dimana pada tahap pra siklus nilai rata-rata mahasiswa hanya 61,3 dan meningkat pada siklus 1 menjadi 75,7 dan meningkat lagi menjadi 83,09 pada siklus 2 .
\end{abstract}

Kata Kunci: Strategi Pembelajaran, Model learning together, Pembelajaran kooperatif, diskusi kelompok

\section{Increasing Activity and Student Learning Outcomes Through Methods of Discussion Group Based on Cooperative Learning Model Learning Together on Marketing Concentration Lesson at Economic Faculty University of Muhammadiyah Sumatera Utara}

\begin{abstract}
This study aims to determine the extent to which students can be actively involved in the classroom by using group discussion methods based on cooperative learning model learning together, and also to know the extent to which students can express opinions and give responses to the opinions of his classmates communicatively by using the method of discussion group learning cooperative learning model together. The approach used is through classroom action research (Classroom Action Research), through cooperative learning methods. Steps taken with stages: (1) plan, (2) action, (3) observation, (4) reflection. The results showed that: (1) During the learning process using the method of group discussion based on cooperative learning method of learning together student learning activity can increase because students are empowered and given trust and actively involved in learning activities. The average percentage achievement of students' learning activity continues to increase which in pre cycle stage is only 34,1\%, then reaching $65,8 \%$ percentage in cycle 1 and increasing again to $92 \%$ in cycle 2. (2) Positive impact from increasing activeness learning is on student learning outcomes which also experienced an increase wherein the precycle cycle the average value of students only 61.3 and increased in the cycle 1 to 75.7 and increased again to 83.09 on cycle 2.
\end{abstract}

Keywords: Learning Strategy, Model learning together, Cooperative learning, group discussion

How to cite:

Andriany, D., dan Arianty, N. (2017). Meningkatkan Keaktifan Dan Hasil Belajar Mahasiswa Melalui Metode Diskusi Kelompok Berbasis Pembelajaran Kooperatif Model Learning Together Pada Matakuliah Konsentrasi Pemasaran Di Fakultas Ekonomi Universitas Muhammadiyah Sumatera Utara. Jurnal Ilmiah Manajemen \& Bisnis, 18(1), 115-128. 


\section{PENDAHULUAN}

Matakuliah konsentrasi pemasaran merupakan suatu mata kuliah wajib yang harus diikuti mahasiswa Fakultas Ekonomi jurusan manajemen konsentrasi pemasaran Universitas Muhammadiyah Sumatera Utara pada saat mereka memasuki semester lima dan semester enam. Pada umumnya mahasiswa menganggap mata kuliah konsentrasi pemasaran ini merupakan mata kuliah yang orientasinya hanya menjual produk saja. Padahal matakuliah konsentrasi pemasaran ini adalah mata kuliah yang banyak menggambarkan kehidupan nyata sehari hari yang nantinya akan dapat berguna bagi mahasiswa apabila mereka sudah

Penggunaan metode diskusi kelompok pun belum mampu melibatkan setiap mahasiswa ke dalam kegiatan pembelajaran secara aktif, kreatif, efektif, dan menyenangkan. Hanya mahasiswa tertentu yang terlibat dalam proses diskusi secara dialogis dan interaktif. Akibatnya, mata kuliah konsentrasi pemasaran belum mampu menjadi mata kuliah yang disenangi dan dirindukan oleh mahasiswa. Imbas lebih jauh dari kondisi pembelajaran semacam itu adalah kegagalan mahasiswa dalam menyusun seminar proposal untuk penulisan skripsi. Untuk mata kuliah konsentrasi seharusnya mahasiswa sudah bisa berpikir kritis dalam memecahkan masalah kasus kasus pemasaran, sebenarnya kalau dilihat penilaian secara objektif, masih banyak mahasiswa yg bernilai jelek (dibawah rata rata atau nilai c ke bawah). Sebahagian besar mahasiswa (mungkin sekitar 50\%) pada saat seminar proposal mereka masih belum begitu memahami apa yang harus mereka kerjakan dalam penelitian. Mungkin hal ini disebabkan pada saat mereka mengikuti mata kuliah konsentrasi mahasiswa belum begitu memahami tentang mata kuliah yang diambil, seharusnya apabila mereka sudah benar benar memahami mata kuliah yang diambil untuk semester 5 dan 6, seharusnya pada saat mereka seminar proposal mereka sudah benar benar memahami.

Kurangnya antusias mahasiswa dalam belajar mata kuliah konsentrasi pemasaran di di kelas dapat disiasati dengan melibatkan mereka secara langsung dalam tiap prosesnya. Dosen hanya sebagai fasilitator dalam mengembangkan ide dari para mahasiswa. Sebagai seorang pengajar melihat bahwa kebanyakan mahasiswa saat ini begitu aktif dan bersemangat apabila mengikuti kegiatan praktik di lapangan (ektrakurikuler). Di sisi lain, saat proses belajar mengajar berlangsung minat mereka untuk mengikuti mata kuliah menurun .

\section{KAJIAN TEORI \\ Hasil Belajar}

Hasil belajar adalah segala sesuatu yang diperoleh siswa setelah melakukan pembelajaran. Hasil belajar pada hakekatnya adalah perubahan tingkah laku, yaitu perubahan tingkah laku dalam ranah kognitif, afektif, dan psikomotor. Hasil belajar adalah kemampuan-kemampuan yang dimiliki siswa setelah ia menerima pengalaman belajarnya (Nana, 2011). Berkaitan dengan prestasi atau kemampuan siswa yang diperoleh setelah hasil belajar Bloom (Nana, 2011) membagi hasil belajar dalam tiga ranah atau kawasan yaitu :

1) ranah kognitif biasanya berkenaan dengan hasil belajar intelektual yang terdiri dari enam aspek, yaitu pengetahuan atau ingatan, pemahaman, aplikasi, analisis, sintesis dan evaluasi.

2) ranah psikomotorik bekenaan dengan hasil belajar keterampilandan kemampuan bertindak. Ada enam aspek psikomotor yaitu gerakan refleks, keterampilan gerakan dasar, kemampuan perseptual, keharmonisan atau ketepatan, gerakan 
keterampilan kompleks, gerakan aspresif dan gerakan interpretatif.

3) ranah afektif berkaitan dengan sikap yang terdiri dari lima aspek, yakni penerimaan, jawaban atau reaksi, penilaian, organisasi, dan internalisasi. Hasil belajar yang diperoleh siswa melalui proses pembalajaran dapat diketahui dengan melakukan evaluasi atau tes, kemudian hasil tes dinilai olehguru. Hasil pengukuran dan penilaian (evaluasi) tidak hanya berguna untuk menilai penguasaan siswa atas berbagai hal yang pernah diajarkan melainkan juga untuk memberikan gambaran tentang pencapaian program-program pendidikan secara lebih menyeluruh. pendidikan pendidikan secara lebih menyeluruh.

\section{Keaktifan Belajar}

\section{a. Pengertian Keaktifan}

Keaktifan yang dimaksud dalam penelitian ini adalah keaktifan belajar mahasiswa siswa dikelas. Menurut kamus besar Bahasa Indonesia (2001 ) aktif adalah giat (bekerja, berusaha), sedangkan keaktifan adalah suatu keadaan atau hal dimana siswa aktif. Belajar adalah proses perubahan tingkah laku kearah yang lebih baik dan relatif tetap,serta ditunjukkan dalam berbagai bentuk seperti berubahnya pengetahuan, pemahaman, sikap, tingkah laku, ketrampilan, kecakapan, kebiasaan, serta perubahan aspek-aspek lain yang ada pada individu yang belajar..

Paul B. Diedrich dalam (Oemar Hamalik 2005) membagi kegiatan belajar siswa dalam 8 kelompok, yaitu:
1) Visual activeties (kegiatan- kegiatan visual) seperti membaca, mengamati

eksperimen, demonstrasi, pameran, dan mengamati orang lain bekerja atau bermain.

2) Oral Activities (kegiatankegiatan lisan) seperti mengemukakan suatu fakta, menghubungkan sutu kejadian, mengajukan pertanyaan, memberi saran, mengemukakan pendapat, wawancara, diskusi, dan interupsi.

3) Listening Activities (kegiatankegiatan mendengarkan) seperti mendengarkan uraian, percakapan, diskusi, musik, pidato, dan sebagainya.

4) Writing activities (kegiatankegiatan menulis) seperti menulis cerita karangan, laporan, tes, angket, menyalin, dan sebagainya.

5) Drawing activities (kegiatankegiatan menggambar) seperti menggambar, membuat grafik, peta, diagaram, pola, dan sebagainya.

6) Motor activities (kegiatankegiatan motorik) seperti melakukan percobaan, membuat konstruksi, model bermain, berkebun, memelihara binatang, dan sebagainya.

7) Mental activities (kegiatankegiatan mental) seperti merenungkan, mengingat, memecahkan masalah, menganalisis, melihat hubungan, mengambil keputusan, dan sebagainya.

8) Emotional activities (kegiatankegiatan emosional) seperti menaruh minat, merasa bosan, gembira, berani, tenang, gugup, dan sebagainya.

b. Faktor yang mempengaruhi keaktifan 


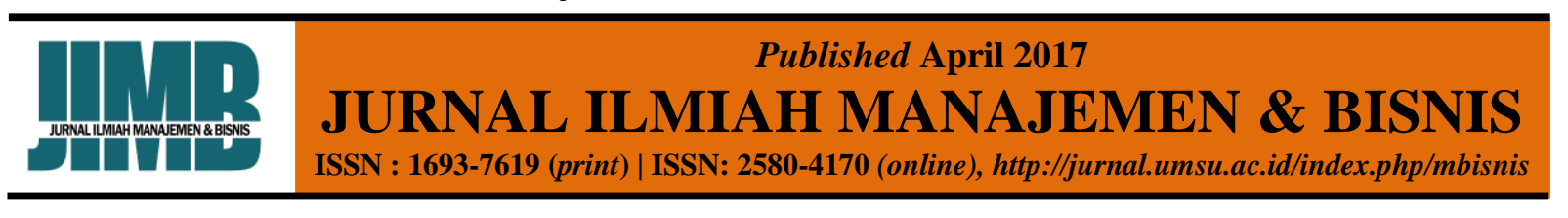

Keaktifan siswa dalam proses pembelajaran dapat merangsang dan mengembangkan bakat yang dimilikinya,siswa juga dapat berlatih untuk berpikir kritis. Menurut Gagne dan Brings (dalam Martinis,2007) faktor- faktor yang dapat menumbuhkan timbulnya keaktifan siswa dalam proses pembelajaran yaitu:

a) Memberikan motivasi atau menarik perhatian siswa, sehingga mereka berperan aktif dalam kegiatan pembelajaran.

b) Menjelaskan tujuan instruksional (kemampuan dasar kepada siswa).

c) Memberikan stimulus (masalah, topik, dan konsep yang akan dipelajari).

d) Memberi petunjuk siswa cara memepelajarinya

e) Memunculkan aktifitas, partisifasi siswa dalam kegiatan pembelajaran.

f) Memberi umpan balik (feed back).

g) Melakukan tagihan- tagihan terhadap siswa berupa tes, sehingga kemampuan siswa selalu terpantau dan terukur.

h) Menyimpulkan setiap materi yang akan disampaikan diakhir pembelajaran.

\section{Metode Pembelajaran}

Dalam proses belajar-mengajar, dosen harus memiliki strategi, agar mahasiswa dapat belajar secara efektif dan efisien, mengena pada tujuan yang diharapkan. Salah satu langkah untuk memiliki strategi itu ialah harus menguasai teknik-teknik penyajian atau bisa disebut metode mengajar. Menurut Winarno S (1986), metode adalah cara yang sebaik-baiknya untuk mencapai tujuan disegala lapangan kehidupan untuk mencari efisiensi agar mencapai suatu keberhasilan. Metode tidak terlepas dengan adanya cara yang direncanakan agar tercapai efisiensi dalam mencapai suatu tujuan. Dengan demikian dapat dikatakan metode adalah suatu prosedur untuk mencapai tujan yang efektif dan efisien. Metode mengajar yang diterapkan seorang pengajar sangat tergantung dari kebiasaan yang dikembangkan berdasarkan pengalaman dan tujuan tertentu. Metode adalah a way in achieving something cara untuk mencapai sesuatu. Berbeda dengan strategi, yang diartikan sebagai ' $a$ plan of operations achieving something' rencana kegiatan untuk mencapai sesuatu. Dengan demikian metode termasuk dalam perencanaan kegiatan.. Dalam kegiatan proses belajar mengajar, metode ceramah merupakan salah satu metode konvensial dan masih tetap digunakan dalam strategi belajar mengajar. Metode ini boleh dikatakan metode yang paling tua, dan masih banyak sekali yang menggunakannya. Bahkan dewasa ini, metode ceramah masih tetap digunakan dan dipertahankan.. Metode diskusi melalui kerja kelompok adalah salah satu metode belajar mengajar yang sering dikembangkan dalam model pembelajaran. Metode diskusi ini terjadi interaksi antara dua atau lebih individu yang terlibat, saling tukar menukar pengalaman, informasi, memecahkan masalah. Diharapkan semua mahasiswa aktif, tidak ada yang pasif sebagai pendengar saja.

\section{Pembelajaran Kooperatif}

Menurut Davidson dan Warsham (dalam Isjoni, 2011), "Pembelajaran kooperatif adalah model pembelajaran yang mengelompokkan siswa untuk tujuan menciptakan pendekatan pembelajaran yang berefektifitas yang mengintegrasikan keterampilan sosial yang bermuatan akademik".

Slavin (dalam Isjoni, 2011) menyatakan bahwa "pembelajaran 
kooperatif adalah suatu model pembelajaran dimana siswa belajar dan bekerja sama dalam kelompok-kelompok kecil secara kolaboratif yang anggotanya terdiri dari 4-6 orang dengan struktur kelompok heterogen". Jadi dalam model pembelajaran kooperatif ini, siswa bekerja sama dengan kelompoknya untuk menyelesaikan suatu permasalahan. Dengan begitu siswa akan bertanggung jawab atas belajarnya sendiri dan berusaha menemukan informasi untuk menjawab pertanyaan-pertanyaan yang diberikan pada mereka.

Berdasarkan uraian di atas, dapat disimpulkan bahwa model pembelajaran kooperatif adalah model pembelajaran yang mengutamakan pembentukan kelompok yang bertujuan untuk menciptakan pendekatan pembelajaran yang efektif.

a. Tujuan Model Pembelajaran Kooperatif Johnson \& Johnson (dalam Trianto, 2010) menyatakan bahwa tujuan pokok belajar kooperatif adalah memaksimalkan belajar siswa untuk peningkatan prestasi akademik dan pemahaman baik secara individu maupun secara kelompok. Louisell dan Descamps (dalam Trianto, 2010) juga menambahkan, karena siswa bekerja dalam suatu tim, maka dengan sendirinya dapat dapat memperbaiki hubungan diantara para siswa dari latar belakang etnis dan kemampuan, mengembangkan keterampilanketerampilan proses dan pemecahan masalah.

Jadi inti dari tujuan pembelajaran kooperatif adalah untuk meningkatkan partisipasi siswa, memfasilitasi siswa, dan memberikan kesempatan pada siswa untuk berinteraksi dan belajar bersamasama siswa lainnya.

b. Prinsip Dasar Model Pembelajaran Kooperatif

Menurut Nur (dalam Widyantini, 2006), prinsip dasar dalam pembelajaran kooperatif sebagai berikut:
1) Setiap anggota kelompok bertanggung jawab atas segala sesuatu yang dikerjakan dalam kelompoknya dan berpikir bahwa semua anggota kelompok memiliki tujuan yang sama.

2) Dalam kelompok terdapat pembagian tugas secara merata dan dilakukan evaluasi setelahnya.

3) Saling membagi kepemimpinan antar anggota kelompok untuk belajar bersama selama pembelajaran.

4) Setiap anggota kelompok bertanggungjawab atas semua pekerjaan kelompok.

Ciri-ciri model pembelajaran kooperatif menurut Nur (dalam Widyantini, 2006) sebagai berikut:

1) Siswa dalam kelompok bekerja sama menyelesaikan materi belajar sesuai kompetensi dasar yang akan dicapai.

2) Kelompok dibentuk secara heterogen.

3) Penghargaan lebih diberikan kepada kelompok, bukan kepada individu.

\section{Metode Diskusi Kelompok Model \\ Learning Together}

Ada beberapa model diskusi kelompok berbasis pembelajaran kooperatif (Depdiknas 2005) antara lain sebagai berikut.

1) Student Teams-Achievement Divisions (STAD) yang menggunakan langkah pembelajaran di kelas dengan menempatkan siswa ke dalam tim campuran berdasarkan prestasi, jenis kelamin, dan suku.

2) Team-Assisted Individualization (TAI) yang lebih menekankan pengajaran individual meskipun tetap menggunakan pola kooperatif.

3) Cooperative Integrated Reading and Composition (CIRC) yang digunakan 
untuk pembelajaran membaca dan menulis tingkat tinggi.

4) Jigsaw yang mengelompokkan siswa ke dalam tim beranggotakan enam orang yang memelajari materi akademik yang telah dibagi-bagi menjadi beberapa subbab.

5) Learning together (belajar bersama) yang melibatkan siswa untuk bekerja dalam kelompok beranggotakan empat atau lima siswa heterogen untuk menangani tugas tertentu.

6) Group Investigation (penelitian kelompok) berupa pembelajaran kooperatif yang bercirikan penemuan

\section{METODE \\ Rencana Tindakan}

Dosen selalu berupaya untuk mendorong mahasiswa aktif di dalam kelas. Penerapan metode diskusi kelompok berbasis pembelajaran kooperatif model lerning together lebih mendorong keaktifan, kemandirian serta rasa tanggaung jawab yang besar pada diri mahasiswa. Berdasarkan paparan di atas maka kerangka penelitian yang akan dilakukan dalam penelitian ini dapat digambarkan sebagai berikut

\section{Pra Penelitian}

Selama ini digunakan

Metode pembelajaran diskusi kelompok yang tidak berbasis pembelajaran kooperatif model learning together sehingga hanya sebahagian mahasiswa saja yang aktif, sementara yang lainnya pasif, akibatnya hasil belajar mahasiswa masih rendah

\section{Tindakan}

\begin{tabular}{|c|}
\hline 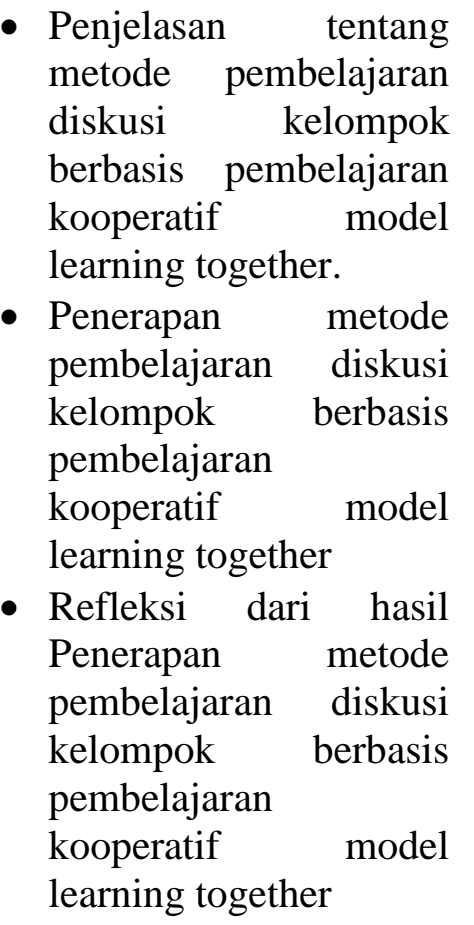 \\
\hline
\end{tabular}

\section{Hasil Penelitian}

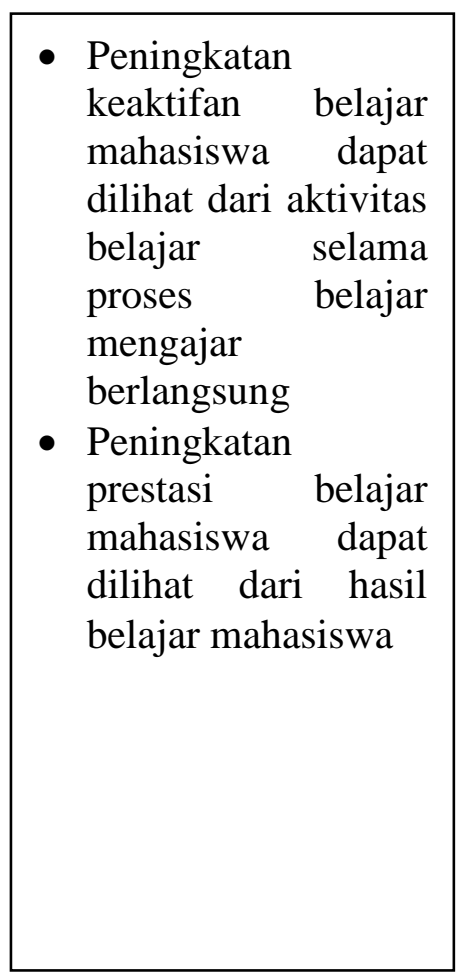

\section{Gambar 3.1 Kerangka Penelitian}

Adapun langkah - langkah tahapan yang akan dilakukan dalam penelitian ini adalah ;

a. Perencanaan

Pada tahap ini, dosen mempersiapkan silabus, rencana pelaksanaan pembelajaran, hand out, lembar kerja mahasiswa, angket, lembar observasi pelaksanaan pembelajaran metode diskusi kelompok berbasis pembelajaran kooperatif model learning together, serta pedoman wawancara

b. Tindakan

Pada tahap tindakan ini dilakukan oleh dosen dengan menerapkan metode diskusi kelompok berbasis pembelajaran 
kooperatif model learning together. Proses pembelajaran dilakukan sesuai dengan jadwal mata kuliah konsentrasi pemasaran. Materi yang diberikan adalah kasus-kasus pemasaran. Adapun tindakan yang akan dilakukan yaitu ;

- langkah pertama, kelas dibagi dahulu menjadi beberapa kelompok tergantung dari jumlah mahasiswa. Biasanya membagi satu kelompok maksimal 5 mahasiswa. Kelompok tersebut kemudian ditunjuk seorang mahasiswa untuk menjadi ketua kelompok.

- Langkah kedua, Dosen menyampaikan materi seperti biasa, terserah memakai metode apa bisa metode pembelajaran ceramah, alat peraga atau campuran metode lainnya.

- Langkah ketiga, memulai diskusi dengan memberi beberapa masalah yang harus diselesaikan oleh tiaptiap kelompok. Disinilah fokus dari semua kegiatan pembelajaran. Bagaimana sebuah kelompok diskusi memecahkan masalah yang pada prinsipnya dapat merangsang mahasiswa yang mengalami kesulitan menangkap pelajaran menjadi aktif meskipun terdapat masalah-masalah lainnya. Diharapkan teman dalam kelompok dapat membantu mahasiswa yang agak lemah menjadi agak terdorong untuk bisa karena terbantu oleh teman-teman satu kelompok.

- Langkah keempat adalah penilaian secara kelompok dan individu yang dilakukan oleh Dosen.

c. Refleksi

Pada tahap ini dosen melakukan evaluasi dari pelaksanaan tindakan di atas apakah proses pembelajaran seperti ini dapat berhasil.

\section{Teknik Pengumpulan Data}

Teknik Pengumpulan data yang digunakan adalah ;

a. Observasi

Dalam penelitian ini dilakukan observasi pelaksanaan pembelajaran yang difokuskan pada aktivitas setiap mahasiswa selama proses belajar mengajar berlangsung. Dan pengamatan yang belum terdapat pada lembar pedoman observasi dituliskan pada lembar catatan lapangan.

b. Angket

Angket dibagikan dan diisi oleh para mahasiswa yang isinya untuk mengetahui tanggapan mahasiswa terhadap pelaksanaan pembelajaran metode diskusi kelompok berbasis pembelajaran kooperatif model learning together.

c. Test

Test digunakan berupa kuis individu yang fungsinya untuk mengetahui tingkat pemahaman mahasiswa setelah mempelajari materi yang terdapat dalam mata kuliah konsentrasi pemasaran dengan menggunakan metode diskusi kelompok berbasis pembelajaran kooperatif model learning together.

d. Dokumentasi

Dokumentasi diperoleh dari hasil kuis mahasiswa, lembar observasi, catatan lapangan, daftar kelompok mahasiswa dan foto - foto selama proses pembelajaran.

\section{Teknik Analisis Data}

Teknik analisis data dilakukan dengan teknik yang digunakan adalah reduksi data. Penyajian data berupa sekumpulan informasi dalam bentuk test naratif yang disusun, diatur dan diringkas sehingga mudah dipahami. Hal ini dilakukan secara bertahap kemudian dilakukan penyimpulan dengan cara diskusi. Untuk menjamin kebenaran dan kemantapan data yang 


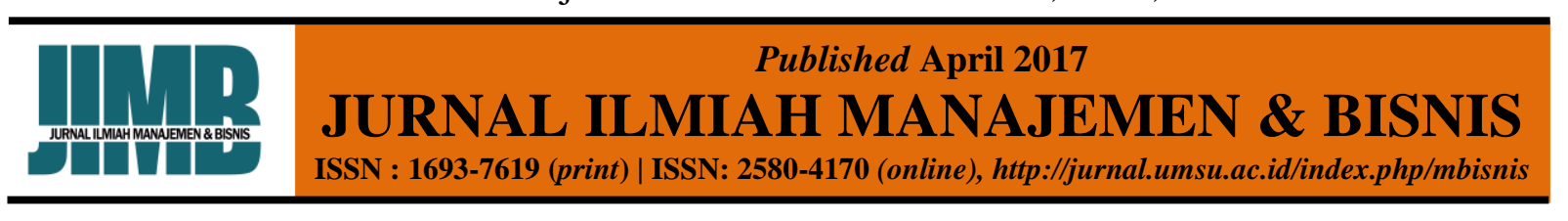

dikumpulkan dan dicatat dalam penelitian digunakan triangulasi diartikan sebagai teknik pengumpulan data yang bersifat menggabungkan dari berbagai teknik pengumpulan data dan sumber data yang telah ada (Sugiyono, 2005).

\section{HASIL DAN PEMBAHASAN \\ Hasil \\ Pra Siklus}

Kegiatan pra siklus ini meliputi persiapan SAP dan GBPP, membuat format observasi keaktifan mahasiswa, membuat test formatif, membuat format kegiatan pembelajaran, membuat jadwal penelitian dan melihat kondisi riil. Pada tahap ini juga mahasiswa sudah dibagi ke dalam kelompok dimana satu kelompok terdiri dari 6 (enam) orang. Saat pra siklus ini aktivitas belajar mahasiswa maupun prestasi belajar masih dalam kondisi rendah, hal ini terlihat dari keaktifan bertanya mahasiswa yang kurang, mahasiswa belum memiliki kesadaran menulis hal-hal yang relevan dengan pembelajaran. Presentase keaktifan mahasiswa dapat dilihat dari tabel berikut :

Tabel 1 Keaktifan Belajar

\begin{tabular}{|l|l|c|c|}
\hline No. & \multicolumn{1}{|c|}{ Deskripsi Keaktifan Belajar } & $\begin{array}{c}\text { Jumlah } \\
\text { Mahasiswa }\end{array}$ & Presentase (\%) \\
\hline 1 & Mahasiswa aktif & 23 & $54,7 \%$ \\
\hline 2 & Mahasiswa Koperatif & 20 & $47,6 \%$ \\
\hline 3 & Mahasiswa dpt menyelesaikan test & 2 & $4,7 \%$ \\
\hline Rata rata presentasi keaktifan belajar mahasiswa & & $34,1 \%$ \\
\hline
\end{tabular}

Hasil belajar sebahagian mahasiswa belum mencapai KKM (Kriteria Ketuntasan Minimal (KKM) yang ditunjukkan dari nilai test dimana hanya 2 orang mahasiswa $(4,7 \%)$ saja yang dapat menyelesaikan test seperti terlihat dalam tabel berikut ;

Tabel 2 Hasil Test Mahasiswa (Pra Siklus)

\begin{tabular}{|l|c|c|c|}
\hline \multicolumn{1}{|c|}{ Skor Nilai } & Jumlah Mahasiswa & Presentase (\%) & Ketercapaian \\
\hline $\mathrm{A}=85 \mathrm{~s} / \mathrm{d} 100$ & - & - & - \\
\hline $\mathrm{B} / \mathrm{A}=80 \mathrm{~s} / \mathrm{d} 84$ & - & - & - \\
\hline $\mathrm{B}=75 \mathrm{~s} / \mathrm{d} 79$ & 2 & $14,7 \%$ & Belum Tercapai \\
\hline $\mathrm{C} / \mathrm{B}=70 \mathrm{~s} / \mathrm{d} 74$ & 6 & $21,4 \%$ & Belum Tercapai \\
\hline $\mathrm{C}=65 \mathrm{~s} / \mathrm{d} 69$ & 9 & $35,7 \%$ & Belum Tercapai \\
\hline $\mathrm{D} / \mathrm{C}=60 \mathrm{~s} / \mathrm{d} 64$ & 15 & $9,5 \%$ & Belum Tercapai \\
\hline $\mathrm{D}=55 \mathrm{~s} / \mathrm{d} 59$ & 4 & $14,3 \%$ & Belum Tercapai \\
\hline $\mathrm{E}=,<55$ & 6 & & \\
\hline Nilai tertinggi : 75 & & \\
\hline Nilai terendah : 50 & & \\
\hline Rata - rata nilai $61,3 \%$ & & \\
\hline
\end{tabular}

\section{Siklus Pertama}

Pada siklus pertama peneliti melakukan empat tahapan kegiatan sebagai berikut :

\section{1). Perencanaan ( Planing )}

- Tim peneliti melakukan analisis kurikulum untuk mengetahui kompetensi dasar yang akan disampaikan kepada mahasiswa dengan menggunakan pembelajaran kooperatif model learning
together.Kompetensi dasar yang harus dimiliki mahasiswa terkait dengan topik bahasan ini adalah mahasiswa mampu mendiskripsikan komponen dari pokok bahasan mata kuliah ini

- Membuat rencana pembelajaran kooperatif model learning together. Rencana pembelajaran / SAP disusun secara khusus disesuaikan dengan tujuan dari penelitian ini 
- Membuat instrumen yang digunakan dalam pengamatan siklus penelitian tindakan kelas

- Menyusun alat evaluasi pembelajaran

2). Pelaksanaan (Acting)

- Membentuk kelompok yang terdiri dari 6 (enam) orang mahasiswa yang anggotanya heterogen. Karena jumlah mahasiswa dalam satu kelas ada 42 mahasiswa maka mahasiswa dibagi menjadi 7 kelompok.

- Memberitahu mahasiswa tentang tugas yang harus dikerjakan oleh anggota kelompok. Tugas kelompok adalah menjawab kuis dalam bentuk kasus dan soal yang dinilai dalam kelompok.

- Menyampaikan tujuan pembelajaran yang hendak dicapai

- Menyampaikan/mempresentasikan materi kuliah di dalam kelas. Materi kuliah dengan berbagai topik tentang manajemen pemesaran starategik disampaikan dengan metode ceramah , diskusi kelas dan penugasan dengan alat bantu lembar kerja .

- Memberikan dan mengumpulkan skor kepada mahasiswa yang menjawab benar.

- Mengumumkan hasil penilaian

- Memberikan penghargaan terhadap usaha-usaha yang telah dilakukan oleh individu maupun oleh kelompok.

Pada Siklus pertama ini aktivitas belajar mahasiswa maupun prestasi belajar mahasiswa sudah mulai meningkat, hal ini terlihat dari keaktifan bertanya mahasiswa yang mulai meningkat menjawab pertanyaan secara koperatif. Presentase keaktifan mahasiswa dapat dilihat dari tabel berikut :

Tabel 3 Keaktifan Belajar (Siklus 1)

\begin{tabular}{|c|l|c|c|}
\hline No. & \multicolumn{1}{|c|}{ Deskripsi Keaktifan Belajar } & Jumlah Mahasiswa & Presentase (\%) \\
\hline 1 & Mahasiswa aktif & 29 & $69 \%$ \\
\hline 2 & Mahasiswa Koperatif & 25 & $59,5 \%$ \\
\hline 3 & Mahasiswa dpt menyelesaikan test & 29 & $69 \%$ \\
\hline \multicolumn{2}{|c|}{ Rata - rata keaktifan belajar mahasiswa } & & $65,8 \%$ \\
\hline
\end{tabular}

Bila dirata - rata keaktifan belajar mahasiswa dalam kegiatan pembelajaran meningkat menjadi sebesar 65,8 \%, demikian juga hasil belajar sebahagian mahasiswa sudah mencapai KKM (Kriteria
Ketuntasan Minimal) yang ditunjukkan dari nilai test dimana sebesar $69,02 \%$ dapat menyelesaikan test seperti terlihat dalam tabel berikut ;

Tabel 4. Hasil Test Mahasiswa (Siklus 1)

\begin{tabular}{|l|c|c|c|}
\hline \multicolumn{1}{|c|}{ Skor Nilai } & Jumlah Mahasiswa & Presentase $\mathbf{( \% )}$ & Ketercapaian \\
\hline $\mathrm{A}=85 \mathrm{~s} / \mathrm{d} 100$ & 10 & 23,8 & Tercapai \\
\hline $\mathrm{B} / \mathrm{A}=80 \mathrm{~s} / \mathrm{d} 84$ & 10 & 23,8 & Tercapai \\
\hline $\mathrm{B}=75 \mathrm{~s} / \mathrm{d} 79$ & 9 & 21,42 & Tercapai \\
\hline $\mathrm{C} / \mathrm{B}=70 \mathrm{~s} / \mathrm{d} 74$ & 4 & 9,5 & Belum Tercapai \\
\hline $\mathrm{C}=65 \mathrm{~s} / \mathrm{d} 69$ & 7 & 16,6 & Belum Tercapai \\
\hline $\mathrm{D} / \mathrm{C}=60 \mathrm{~s} / \mathrm{d} 64$ & 2 & 4,7 & \\
\hline $\mathrm{D}=55 \mathrm{~s} / \mathrm{d} 69$ & - & & \\
\hline $\mathrm{E}=,<55$ & - & & \\
\hline Nilai tertinggi $; 85$ & & & \\
\hline Nilai terendah $; 60$ & & \\
\hline Rata - rata nilai $: 75,7 \%$ & & \\
\hline
\end{tabular}


Sedangkan hasil dari kuis yang dilakukan dalam kelompok disajikan dalam tabel berikut ini. Nilai tabel tersebut di bawah ini dianalisis untuk diketahui nilai peningkatannya untuk kemudian dikategorisasi dengan kriteria sebagai berikut :

- Cukup, bila rata-rata nilai peningkatan kelompok kurang dari 10 (Rata-rata nilai peningkatan kelompok < 10).
- Baik, bila rata-rata nilai peningkatan kelompok antara 10 dan 15 ( $10 \leq$ Ratarata nilai peningkatan kelompok < 15)

- Sangat baik, bila rata-rata nilai peningkatan kelompok antara 15 dan 20 $(15 \leq$ Rata-rata nilai peningkatan $<20)$

- Sempurna, bila rata-rata nilai peningkatan kelompok lebih atau sama dengan 20 (Rata-rata nilai peningkatan kelompok $\geq 20$ ).

Tabel 5. Hasil Skore kuis / siklus 1

\begin{tabular}{|c|c|c|c|c|}
\hline Kelompok & Nilai Awal & Nilai Terkini & $\begin{array}{c}\text { Nilai Peningkatan } \\
\text { Kelompok }\end{array}$ & Predikat \\
\hline 1 & 60 & 75 & 15 point & Tim baik \\
\hline 2 & 62,5 & 76,6 & 14,1 point & Tim baik \\
\hline 3 & 45 & 69,1 & 24,1 point & Tim super \\
\hline 4 & 62,5 & 79,1 & 16,6 point & Tim hebat \\
\hline 5 & 63,3 & 75,8 & 12,5 point & Tim baik \\
\hline 6 & 60,8 & 74,1 & 13,3 point & Tim baik \\
\hline 7 & 53,3 & 78,3 & 25 point & Tim super \\
\hline
\end{tabular}

Sumber : Data Primer yang diolah 2015

3). Pengamatan ( Observation )

Tindakan peneliti yang dilakukan pada tahapan ini adalah sebagai berikut :

- Mengamati situasi kegiatan selama proses pembelajaran. Kondisi yang diamati meliputi suasana ruang kelas, kelancaran proses belajar mengajar, hasil yang diperoleh, dan sebagainya.

- Mengamati keaktifan mahasiswa. Mengamati tingkat partisipasi masing masing mahasiswa dalam kelompok dan melihat keaktifan mahasiswa dalam menjawab kuis kuis yang diberikan pada kelompoknya.

- Mengamati Kemampuan mahasiswa setelah melakukan diskusi dan untuk melhat sejauh mana tujuan pembelajaran / kompetensi dasar dikuasai oleh mahasiswa melalui diskusi antar kelompok.

Pada akhir siklus pertama dari hasil pengamatan dosen dapat disimpulkan :
- Sebagian besar mahasiswa sudah mulai aktif dan koperatif dalam mengikuti .proses belajar

- Sebahagian besar mahasiswa juga sudah mencapai KKM (Kriteria Ketuntasan Minimal)

- Sebagian besar kelompok terlihat aktif mengikuti kegiatan pembelajaran

- Mahasiswa mulai terbiasa dengan kondisi belajar kelompok

- Mahasiswa mulai terbiasa dengan pembelajaran kooperatif metode learning together

- Mahasiswa mampu menyimpulkan materi pembelajaran melalui jawaban kuis yang diberikan.

4). Refleksi (Reflecting)

Penelitian tindakan kelas ini berhasil apabila memenuhi beberapa syarat sebagai berikut :

- rata rata peningkatan nilai hasil belajar individu mahasiswa berkisar 20 point 
- $\quad$ rata rata nilai peningkatan hasil belajar kelompok tergolong baik

- $75 \%$ anggota kelompok aktif dalam diskusi kelompok

Untuk memperbaiki kelemahan dan mempertahankan keberhasilan yang telah dicapai pada siklus pertama, maka pada pelaksanaan siklus kedua dapat dibuat perencanaan sebagai berikut:

- Memberikan motivasi kepada kelompok agar lebih aktif lagi dalam pembelajaran.

- Lebih intensif membimbing kelompok yang kurang aktif dalam kegiatan proses belajar mengajar.

- memberi pengakuan atau penghargaan (reward) kepada kelompok

\section{Siklus Kedua (setelah selesai mid semester)}

Siklus kedua dilaksanakan setelah mahasiswa mengikuti ujian pertengahan semester, dimana siklus kedua ini terdiri dari perencanaan, pelaksanaan, observasi, dan refleksi .

\section{1). Perencanaan ( Planing )}

Perencanaan pada siklus kedua berdasarakan perencanaan siklus pertama yaitu :

- Memberikan motivasi kepada kelompok agar lebih aktif lagi dalam proses pembelajaran.
- Lebih intensif membimbing kelompok yang mengalami kesulitan dalam menjawab kuis permainan

- Memberi pengakuan atau penghargaan

- Membuat soal - soal pembelajaran kooperatif metode learning together yang lebih mudah dipahami oleh mahasiswa

2). Pelaksanaan (Acting)

Hasil dari pelaksanaan tahap ini pada siklus dua adalah sebagai berikut :

- Suasana pembelajaran sudah mengarah kepada pembelajaran kooperatif metode learning together

- Sebagian besar mahasiswa merasa termotivasi untuk ikut serta menjawab kuis dan memberikan kontribusi dalam diskusi kelompok

- Suasana pembelajaran yang efektif dan menyenangkan sudah mulai tercipta

Pada Siklus kedua ini aktivitas belajar mahasiswa maupun prestasi belajar mahasiswa sudah terus meningkat, hal ini terlihat dari keaktifan bertanya mahasiswa yang cenderung meningkat dimana mahasiswa menjawab pertanyaan secara koperatif. Presentase keaktifan mahasiswa dapat dilihat dari tabel berikut :

Tabel 6. Keaktifan Belajar (Siklus 2)

\begin{tabular}{|c|l|c|c|}
\hline No. & \multicolumn{1}{|c|}{ Deskripsi Keaktifan Belajar } & Jumlah Mahasiswa & Presentase (\%) \\
\hline 1 & Mahasiswa aktif & 38 & $90,4 \%$ \\
\hline 2 & Mahasiswa Koperatif & 38 & $90,4 \%$ \\
\hline 3 & Mahasiswa dpt menyelesaikan test & 40 & $95,2 \%$ \\
\hline \multicolumn{2}{|c|}{ Rata - rata keaktifan belajar mahasiswa } & & $92 \%$ \\
\hline
\end{tabular}


Bila dirata - rata keaktifan belajar mahasiswa dalam kegiatan pembelajaran meningkat menjadi sebesar $92 \%$, demikian juga hasil belajar sebahagian mahasiswa sudah mencapai KKM (Kriteria Ketuntasan
Minimal) yang ditunjukkan dari nilai test dimana sebesar $95,19 \%$ dapat menyelesaikan test seperti terlihat dalam tabel berikut;

Tabel 7. Hasil test mahasiswa (Siklus 2)

\begin{tabular}{|c|c|c|c|}
\hline Skor Nilai & Jumlah Mahasiswa & Presentase & Ketercapaian \\
\hline $\mathrm{A}=85 \mathrm{~s} / \mathrm{d} 100$ & 32 & $76,19 \%$ & Tercapai \\
\hline $\mathrm{B} / \mathrm{A}=80 \mathrm{~s} / \mathrm{d} 84$ & 4 & $9,5 \%$ & Tercapai \\
\hline $\mathrm{B}=75 \mathrm{~s} / \mathrm{d} 79$ & 4 & $9,5 \%$ & Tercapai \\
\hline $\mathrm{C} / \mathrm{B}=70 \mathrm{~s} / \mathrm{d} 74$ & 2 & $4,81 \%$ & Belum tercapai \\
\hline $\mathrm{C}=65 \mathrm{~s} / \mathrm{d} 69$ & - & - & - \\
\hline $\mathrm{D} / \mathrm{C}=60 \mathrm{~s} / \mathrm{d} 64$ & - & - & - \\
\hline $\mathrm{D}=55 \mathrm{~s} / \mathrm{d} 69$ & - & - & - \\
\hline $\mathrm{E}=,<55$ & - & - & - \\
\hline \multicolumn{4}{|l|}{ Nilai tertinggi : 90} \\
\hline \multicolumn{4}{|l|}{ Nilai terendah : 70} \\
\hline Rata - rata nilai: 80 & & & \\
\hline
\end{tabular}

Sedangkan hasil dari kuis yang dilakukan dalam kelompok disajikan dalam tabel berikut ini ;

Tabel 8 Skore kuis/siklus 2

\begin{tabular}{|c|c|c|c|c|}
\hline Kelompok & $\begin{array}{c}\text { Nilai } \\
\text { Awal }\end{array}$ & $\begin{array}{c}\text { Nilai } \\
\text { Terkini }\end{array}$ & $\begin{array}{c}\text { Nilai Peningkatan } \\
\text { Kelompok }\end{array}$ & Predikat \\
\hline 1 & 75 & 85 & 10 point & Tim baik \\
\hline 2 & 76,6 & 86,6 & 10 point & Tim baik \\
\hline 3 & 69,1 & 85,8 & 16,7 point & Tim hebat \\
\hline 4 & 79,1 & 89,1 & 10 point & Tim baik \\
\hline 5 & 75,8 & 87,5 & 11,7 point & Tim baik \\
\hline 6 & 74,1 & 84,1 & 10 point & Tim baik \\
\hline 7 & 78,3 & 89,1 & 10,8 point & Tim baik \\
\hline
\end{tabular}

Pada siklus rata rata nilai kuis 2 ini terjadi peningkatan rata - rata 10 point. Pada siklus 2 ini bisa dikatakan bahwa nilai peningkatan hasil belajar mahasiswa dengan menggunakan model pembelajaran koperatif metode learning together tergolong berpredikat baik. Nilai rata rata kuis pada siklus sebelumnya adalah 75,7 sedangkan pada akhir siklus 2 adalah 80 . Jadi bisa dikatakan secara umum terjadi peningkatan nilai test individu mahasiswa dibandingkan sebelum menggunakan model pembelajaran kooperatif metode learning together.

3). Observasi dan Evaluasi

Dari hasil observasi setelah dilakukan beberapa perbaikan kegiatan dengan mengaju dari hasil refleksi siklus 1, juga terjadi perubahan pada keaktifan belajar mahasiswa dibandingkan dengan keaktifan belajar pada siklus sebelumnya dan juga 


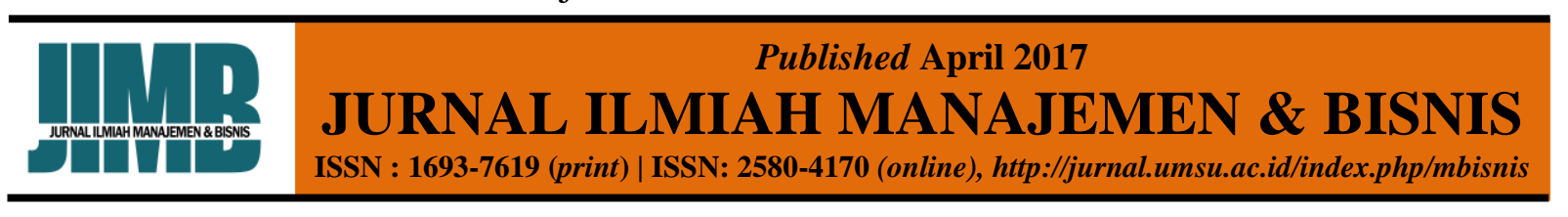

terjadi peningkatan pada nilai test mahasiswa. Untuk jumlah skor hasil pengumpulan data diperoleh hasil sebesar 2286, sedangkan jumlah skor bila setiap butir skor mendapat nilai tertinggi diperoleh nilai sebesar 3.192 , maka persentasi respon mahasiswa terhadap metode pembelajaran ini adalah sebesar 0,716 atau $71,6 \%$ artinya respon mahasiswa terhadap metode pembelajaran ini tinggi.

\section{4). Refleksi}

Adapun keberhasilan yang diperoleh selama siklus kedua ini adalah sebagai berikut :

- Aktivitas mahasiswa dalam proses belajar mengajar sudah mengarah ke pembelajaran kooperatif. Mahasiswa mampu membangun kerja sama dalam kelompok dan memiliki semangat kompetisi untuk memperoleh hasil terbaik.

- Meningkatnya aktivitas mahasiswa dalam proses belajar mengajar didukung oleh meningkatnya peran dosen sebagai fasilitator, mediator, moderator dan organisator dalam mengelola dan menciptakan suasana pembelajaran yang mengarah pada pembelajaran kooperatif model learning together, yaitu suasana kerjasama, saling ketergantungan, dan kompetisi dan semangat memperoleh hasil terbaik bagi kelompoknya.

Secara umum aktivitas atau partisipasi masing masing mahasiswa dalam kelompok pada beberapa siklus dapat dilihat dari tabel berikut:

Tabel 9 Rekapitulasi rata-rata keaktifan mahasiswa

\begin{tabular}{|c|l|c|c|}
\hline NO & \multicolumn{1}{|c|}{ Siklus } & PERSENTASE (\%) & KETERANGAN \\
\hline 1 & Pra Siklus & $34,1 \%$ & \\
\hline 2 & Siklus 1 & $65,8 \%$ & \\
\hline 3 & Siklus 2 & $92 \%$ & \\
\hline
\end{tabular}

Dari data tabel di atas tampak bahwa rata-rata keaktifan belajar mahasiswa pada siklus 1 sebesar 65,8\%, hal ini menunjukkan adanya peningkatan keaktifan belajar mahasiawa jika dibandingkan dengan keadaan pra siklus sebelum menerapakan metode pembelajaran ini dengan peresentasi sebesar $34,1 \%$. Pada siklus 2 rata - rata keaktifan belajar mahasiswa terus meningkat menjadi 92\%, keaktifan belajar mahasiswa ini dikategorikan sangat baik.

Sedangkan hasil test mahasiswa terjadi peningkatan di setiap siklusnya seperti terlihat pada tabel di bawah ini ;

Tabel 10 Rekapitulasi hasil test mahasiswa

\begin{tabular}{|c|l|c|c|c|}
\hline NO & \multicolumn{1}{|c|}{ Tahap } & Nilai Tertinggi & Nilai Terendah & Nilai Rata- Rata \\
\hline 1 & Pra Siklus & 75 & 50 & 61,3 \\
\hline 2 & Siklus 1 & 85 & 60 & 75,7 \\
\hline 3 & Siklus 2 & 100 & 70 & 83,09 \\
\hline
\end{tabular}




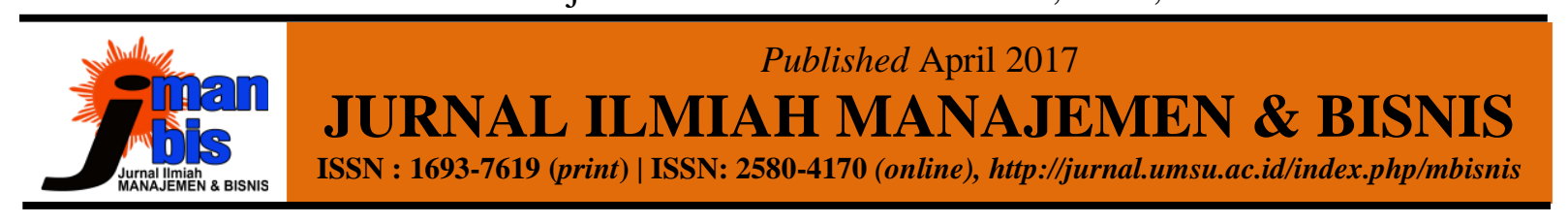

Dari tabel di atas tampak bahwa hasil test mahasiswa setiap siklusnya juga mengalami peningkatan, nilai tertinggi dan terendah juga mengalami peningkatan, hal ini sebagai pengaruh positif dari metode pembelajaran ini.

\section{SIMPULAN}

Berdasarkan pada hasil penelitian dapat ditarik kesimpulan sebagai berikut :

1. Penerapan metode diskusi kelompok berbasis pembelajaran kooperatif metode learning together dapat meningkatkan keaktifan dan hasil belajar mahasiswa dalam pembelajaran mata kuliah konsentrasi pemasaran di Fakultas Ekonomi jurusan Manajemen Universitas Muhammadiyah Sumatera Utara.

1. Selama proses pembelajaran mengunakan metode diskusi kelompok berbasis pembelajaran kooperatif metode learning together keaktifan belajar mahasiswa dapat meningkat karena mahasiswa diberdayakan dan diberi kepercayaan dan terlibat secara aktif dalam kegiatan belajar. Ketercapaian persentase rata-rata keaktifan belajar siswa terus meningkat dimana pada tahap pra siklus hanya sebesar 34,1 \%, kemudian mencapai persentase $65,8 \%$ pada siklus 1 dan meningkat lagi menjadi $92 \%$ pada siklus 2 .

2. Dampak positif dari meningkatnya keaktifan belajar adalah pada hasil belajar mahasiswa yang juga mengalami peningkatan dimana pada tahap pra siklus nilai rata-rata mahasiswa hanya 61,3 dan meningkat pada siklus 1 menjadi 75,7 dan meningkat lagi menjadi 83,09 pada siklus 2

\section{Saran}

Berdasarkan kesimpulan dan implikasi hasil penelitian ini, disarankan : bahwa guna mengembangkan dan memperkaya metode pembelajaran pada mata kuliah konsentrasi pemasaran dapat diterapkan strategi pembelajaran kooperatif melalui penerapan diskusi kelompok secara terbimbing dan terarah. Melalui penerapan model pembelajaran ini, mahasiswa akan sangat terbantu untuk meningkatkan motivasi belajarnya, dengan demikian diharapkan capaian hasil belajar mahasiswa dapat meningkat.

\section{REFERENSI}

Daryono, 2005 , Psikologi Pendidikan ,Jakarta, Rineka Cipta

Hamalik, Oemar,2000, Psikologi Belajar dan Mengajar,Bandung, Sinar Baru Algensindo

Mohamad Nur, 2005, Pembelajaran Kooperatif. Dirjen Dikti Diknas

Pusat Bahasa Depdiknas, 2001, Kamus Besar Bahasa Indonesia, Jakarta, Balai Pustaka

Robert E. Slavin, 1995, Cooeperatif Learning Theory Riset and Practice,Boston, allyn \& Bacon

Sugiyono, 2001,Penelitian Tindakan Kelas, Jakarta, Bumi Aksara

Sudjana, Nana 2011, CBSA,Bandung, Sinar Baru. 